\title{
Synthesis of modified 1,5-imino-D-xylitols as ligands for lysosomal $\beta$-glucocerebrosidase
}

\author{
Manuel Zoidl ${ }^{1}$ - Andreas Wolfsgruber ${ }^{1} \cdot$ Michael Schalli $^{1} \cdot$ Seyed A. Nasseri ${ }^{2} \cdot$ Patrick Weber $^{1} \cdot$ Arnold E. Stütz $^{1}$. \\ Stephen G. Withers ${ }^{2} \cdot$ Tanja M. Wrodnigg ${ }^{1}$ (I)
}

Received: 1 February 2019 / Accepted: 11 April 2019 / Published online: 11 May 2019

(c) The Author(s) 2019

\begin{abstract} selectivities.

\section{Graphical abstract}

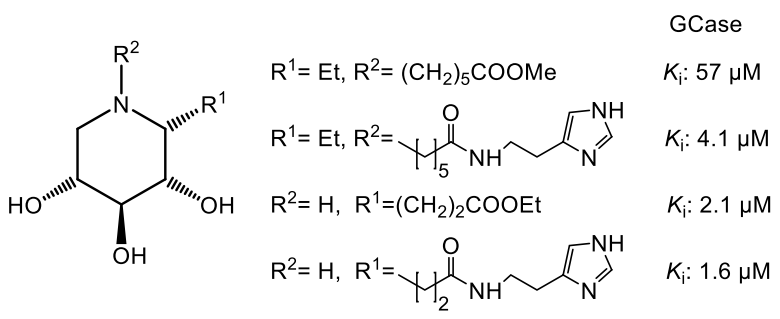

Modified 1,5-dideoxy-1,5-imino-D-xylitol analogues with different substitution patterns involving position C-1 and/or the ring nitrogen were prepared, which were designed to serve as precursors for the preparation of iminoxylitol-based ligands and tools for the elucidation and modulation of human lysosomal $\beta$-glucocerebrosidase. Biological evaluation of the synthesized glycomimetics with a series of glycoside hydrolases revealed that these substitution patterns elicit excellent $\beta$-glucosidase

Keywords Carbohydrates $\cdot$ Conformation $\cdot$ Enzymes $\cdot \beta$-Glucosidase ligands $\cdot$ Iminoxylitol $\cdot \beta$-Glucocerebrosidase

\section{Introduction}

Iminoalditols, also termed iminosugars, are natural occurring glycomimetics, in which the ring oxygen of the carbohydrate moiety is replaced by a trivalent basic nitrogen.

Dedicated to Professor Dr. Heinz Falk on the happy occasion of his 80th birthday anniversary.

Electronic supplementary material The online version of this article (https://doi.org/10.1007/s00706-019-02427-1) contains supplementary material, which is available to authorized users.

Tanja M. Wrodnigg

t.wrodnigg@tugraz.at

1 Institute of Organic Chemistry, Graz University of Technology, Graz, Austria

2 Department of Chemistry, University of British Columbia, 2036 Main Mall, Vancouver, BC V6T 1Z1, Canada
Paradigmatic structural scaffolds are polyhydroxylated piperidines $\mathbf{1}$, pyrrolidines $\mathbf{2}$, indolizidines $\mathbf{3}$, and pyrrolizidines 4 (Fig. 1) [1-5]. The nitrogen in the endocyclic position is responsible for the unique biological behavior of this compound class to interact and modulate active site specifically glycoside-processing enzymes. Since the last decades, such compounds have been of great interest for an interdisciplinary scientific community, including chemists, biochemists, as well as physicians.

Many different naturally occurring structures are known, exceeded by the number of synthetic derivatives, with manifold different modification patterns concerning the carbohydrate scaffold as well as customized derivatisations for different applications. This substance class has been implicated as potential therapeutic agents [6], for example, as immunomodulators $[7,8]$, as antibacterial [9, 10], antiviral [11, 12], anti-cancer [13], and anti-fungal [14] agents. In addition, iminoalditol-based glycomimetics have been 
identified as plant growth inhibitors [15]. An interesting field of application has emerged when iminoalditols have been applied at sub-inhibitory concentrations to act as proteinfolding templates $[16,17]$ for mutant lysosomal enzymes, thus becoming candidates for the management of lysosomal storage disorders in the pharmacological chaperone therapy [18]. Moreover, this compound class has received great attention as probes for activity-based profiling of glycosideprocessing enzymes [19-21].

The D-xylo configuration in the dideoxy iminoalditol scaffold has been shown to have very interesting ligand properties for glycoside-processing enzymes in terms of activity as well as selectivity [22]. Various modifications with respect to substituents as well as positions on the iminoxylitol scaffold have been synthesized and biologically<smiles>OC1CCNCC1</smiles><smiles>C1CC2CCC(O1)O2</smiles><smiles>OC1CN2CC3CC2CC1C3O</smiles><smiles>OC1CCN2CCCCC12</smiles>

Fig. 1 Structures of iminoalditol scaffolds 1-4 investigated. Basically all of these compounds have been shown to be highly selective ligands for $\beta$-glucosidases. For example, fluorinated iminoxylitols carrying an $N$-alkyl group [23] (Fig. 2), such as compound $\mathbf{5}$, have been found to exhibit immunosuppressive as well as glycosidase inhibitory activities. Based on Lehmann's early finding [24], iminoxylitols bearing a guanidino or urea function at the ring nitrogen [25, 26], for example compound $\mathbf{6}$, were synthesized and found to be selective inhibitors of human lysosomal $\beta$-glucocerebrosidase (GCase) with $\mathrm{IC}_{50}$ values in the low nm range. A deficiency of this enzyme causes Gaucher disease [27]. We have synthesized iminoxylitols modified at the endocyclic ring nitrogen with functionalized alkyl groups, such as compound structure 7 [28], as well as featuring more sophisticated substituents, including structure 8 [29]. These compounds exhibited inhibitory properties against $\beta$-xylosidase from Thermoanaerobacterium saccharolyticum (Xyl Therm. sac.), with $K_{\mathrm{i}}$ values in the lower $\mu \mathrm{m}$ range (Table 1).

Martin and co-workers have developed elegant synthetic routes towards 1-C-alkyl imino-D-xylitols 9 (Fig. 3), and showed that the introduction of the substituent at position C-1 improved the ligand properties as well as the
Fig. 2 Structures of $N$-modified DIX derivatives 5-8<smiles>[R]N1C[C@H](O)[C@H](F)[C@H](O)C1</smiles>

5 ref [23]

$\mathrm{R}=\mathrm{H}$

$\mathrm{R}=\left(\mathrm{CH}_{2}\right)_{7} \mathrm{CH}_{3}$

$\mathrm{R}=\left(\mathrm{CH}_{2}\right)_{9} \mathrm{CH}_{3}$<smiles>[R]NC(=O)N1C[C@@H](O)C(O)[C@H](O)C1</smiles>

6 ref [25]<smiles>[R]N1C[C@H](O)[C@H](O)[C@H](O)C1</smiles>

7 ref [28]

$$
\begin{aligned}
& \mathrm{R}=\mathrm{C}_{\mathrm{n}} \mathrm{H}_{\mathrm{n}+1}, \mathrm{n}=8,10,12,14 \\
& \mathrm{R}=\mathrm{CH}_{2} \operatorname{CON}\left(\mathrm{C}_{10} \mathrm{H}_{21}\right)_{2}
\end{aligned}
$$

a: $\mathrm{R}=\left(\mathrm{CH}_{2}\right)_{2} \mathrm{CN}$

$K_{\mathrm{i}}=24 \mu \mathrm{M}$ (Xyl Therm. sac.)

b: $\mathrm{R}=\left(\mathrm{CH}_{2}\right)_{2} \mathrm{CO}_{2} \mathrm{CH}_{3}$ $K_{\mathrm{i}}=35 \mu \mathrm{M}$ (Xyl Therm. sac.)<smiles>[R]C(=O)C([R])CCCCN1C[C@@H](O)C(O)[C@H](O)C1</smiles>

$\mathrm{R}^{1}=\mathrm{NHdansyl}, \mathrm{R}^{2}=\mathrm{OMe}$

$K_{\mathrm{i}}=10 \mu \mathrm{M}$ (Xyl Therm. sac.)<smiles>[R]C=CCNC(C)CCCCN1C[C@H](O)[C@@H](O)[C@H](O)[C@H]1O</smiles>

$K_{\mathrm{i}}=21 \mu \mathrm{M}(\mathrm{Xyl}$ Therm. sac. $)$<smiles>[R]OC#[W]</smiles>

$K_{\mathrm{i}}=25 \mu \mathrm{M}$ (Xyl Therm. sac.) 
Fig. 3 Structures of C-1 modified DIX derivatives 9-11<smiles>[R]C1NC[C@@H](O)[C@H](O)[C@@H]1O</smiles>

$\mathrm{R}=\mathrm{C}_{9} \mathrm{H}_{19}$

$K_{\mathrm{i}}=2.2 \mathrm{nM}$ (GCase)

$\mathrm{R}=\mathrm{C}_{12} \mathrm{H}_{25}$

$K_{\mathrm{i}}=31 \mathrm{nM}$ (GCase)<smiles>[R2]O[C@H]1[C@@H](O)[C@@H](O)CN[C@@H]1[R]</smiles>

10 ref [33]

10a: $R^{1}=\mathrm{C}_{6} \mathrm{H}_{13}, \mathrm{R}^{2}=\mathrm{H}$

$\mathrm{IC}_{50}=19 \mathrm{nM}$ (GCase)

10b: $R^{1}=\mathrm{H}, \mathrm{R}^{2}=\mathrm{C}_{6} \mathrm{H}_{13}$

$\mathrm{IC}_{50}=9 \mathrm{nM}$ (GCase)<smiles>[R]C1NC[C@@H](O)[C@H](O)[C@@H]1O</smiles>

11 ref [34]<smiles>[R]CCCOC(=O)C(C)=O</smiles>

$K_{\mathrm{i}}=1.8 \mathrm{nM}$ (GCase)<smiles>[R]CCC1COC(CC=CC)OCC1=C</smiles>

$K_{\mathrm{i}}=2.2 \mathrm{nM}$ (GCase)<smiles>[R]n1cc(C[C@@H]2NC[C@@H](O)[C@H](O)[C@H]2O)nn1</smiles><smiles>[R]=C=CCCC(c1ccccc1)c1ccccc1</smiles><smiles>CCCc1cc(OCc2ccccc2)cc(OCc2ccccc2)c1</smiles>

12 ref [36]

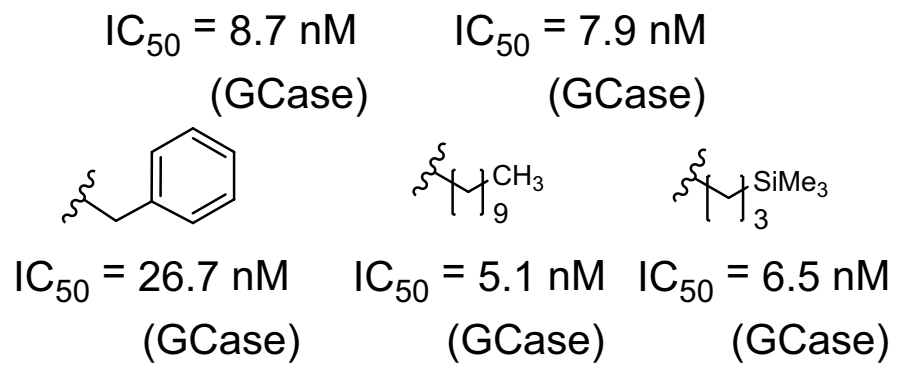

Fig. 4 Structure of C-1 modified DIX derivatives $\mathbf{1 2}$

selectivity for GCase significantly [30-32]. In addition, in a structure-activity study, the influence of the position of an alkyl chain has been investigated, showing that a 1-2 shift of the alkyl substituent from C-1 to O-2 (compounds 10a-10b) increased the inhibitory property of the respective compound against GCase by a factor of 2 [33]. The same group has also synthesized 1,5-dideoxy-1,5-iminoD-xylitol (DIX) derivatives with alkyl substituents similar to ceramide at position C-1, for example compound 11, and obtained highly potent GCase inhibitors which also showed selective chaperone properties for mutations associated to Types 1 and 2 Gaucher Disease [34].

Compain and co-workers synthesized a library of 1-C-triazolylalkyl side chain-modified DIX analogues (Fig. 4), including compounds 12 , by a click chemistry approach, and found that some of these are GCase enhancers for selected Gaucher disease genotype mutants [35, 36].
Withers and co-workers developed a thiol-ene reaction sequence for rapid assembly of 1- $C$-alkyl DIX derivatives containing a sulfur atom between the DIX scaffold and the lipophilic substituent (Fig. 5), such as compounds 13, and also found excellent ligand properties in terms of activity as well as selectivity for GCase furnishing promising potent and selective pharmacological chaperones for GCase mutants [37].

Overkleeft and co-workers included into their structure-activity relationship study of lipophilic glycomimetics various D-xylo configured 1- $C$-iminosugar glycosides, for example compounds 14 (Fig. 6), and could demonstrate that these glycomimetics significantly exceed in terms of inhibitory activity as well as selectivity for GCase compared to the corresponding of D-gluco as well as L-ido configured analogues [38].

We have developed a convenient synthetic protocol for the modification of the DIX scaffold at position C-1 taking 
Fig. 5 Structure of C-1 modified DIX derivatives 13<smiles>[R][CH]C[C@H]1NC[C@@H](O)[C@H](O)[C@H]1O</smiles>

13 ref [37]

$$
\begin{array}{rr}
K_{\mathrm{i}}=\begin{array}{l}
0.4 \mathrm{nM} \\
\text { (GCase) }
\end{array} & \begin{array}{c}
K_{\mathrm{i}}=4 \mathrm{nM} \\
\text { (GCase) }
\end{array} \\
\begin{array}{c}
K_{\mathrm{i}}=4.4 \mathrm{nM} \\
\text { (GCase) }
\end{array}
\end{array}
$$<smiles>CCCc1ccccc1</smiles><smiles>CCCCNC(=O)Nc1ccccc1</smiles>

$$
K_{\mathrm{i}}=3.0 \mathrm{nM}
$$

$K_{\mathrm{i}}=12 \mathrm{nM}$

(GCase)<smiles>[R]C(C)(C)[R]C[C@H]1NC[C@@H](O)[C@H](O)[C@H]1O</smiles>

14 ref [38]

$$
\begin{aligned}
& \mathrm{R}^{1}=\mathrm{C}-\mathrm{C}, \mathrm{n}=2, \mathrm{R}^{2}=\mathrm{O} \\
& \mathrm{R}^{1}=\mathrm{C}-\mathrm{C}, \mathrm{n}=6, \mathrm{R}^{2}=\mathrm{CH}_{3}, K_{\mathrm{i}}=1 \mathrm{nM}(\mathrm{GCase}) \\
& \mathrm{R}^{1}=\mathrm{C}=\mathrm{C}, \mathrm{n}=6, \mathrm{R}^{2}=\mathrm{CH}_{3} K_{\mathrm{i}}=2 \mathrm{nM} \text { (GCase) } \\
& \mathrm{R}^{1}=\mathrm{C}=\mathrm{C}, \mathrm{n}=2, \mathrm{R}^{2}=\mathrm{O}
\end{aligned}
$$

Fig. 6 Structure of C-1 modified DIX derivatives $\mathbf{1 4}$

Fig. 7 Structure of C-1 modified DIX derivatives $\mathbf{1 5}$<smiles>[R]C1NC[C@@H](O)[C@H](O)[C@@H]1O</smiles>

15 ref $[39,40]$

$$
\begin{array}{ll}
\mathrm{R}=\mathrm{CN} & K_{\mathrm{i}}=34 \mu \mathrm{M} \text { (GCase) } \\
\mathrm{R}=\mathrm{CH}_{2} \mathrm{NH}_{\text {dansyl }} K_{\mathrm{i}}=7,5 \mathrm{nM} \text { (GCase) } \\
\mathrm{R}=\mathrm{CH}_{2} \mathrm{CH}_{3} & K_{\mathrm{i}}=2.3 \mu \mathrm{M} \text { (GCase) } \\
\mathrm{R}=\left(\mathrm{CH}_{2}\right)_{2} \mathrm{CH}_{3} & K_{\mathrm{i}}=1.3 \mu \mathrm{M} \text { (GCase) } \\
\mathrm{R}=\mathrm{CH}\left(\mathrm{CH}_{3}\right)_{2} & K_{\mathrm{i}}=12.4 \mu \mathrm{M} \text { (GCase) } \\
\mathrm{R}=\left(\mathrm{CH}_{2}\right)_{2} \mathrm{OH} & K_{\mathrm{i}}=26.7 \mu \mathrm{M} \text { (GCase) }
\end{array}
$$

advantage of the Staudinger/aza-Wittig/nucleophile reaction sequence $[39,40]$. By this method, we have synthesized a range of simple C-1 alkyl modified DIX analogues $\mathbf{1 5}$ (Fig. 7) and have found the same trend for these compounds, which are highly selective ligands for GCase.

All DIX derivatives carrying a substituent at position C-1, 9-15, have been found to be locked in the ${ }^{1} \mathrm{C}_{4}$ conformation when the alkyl substituent is introduced from the $\beta$-face at the pseudoanomeric center (B, Fig. 8). The hydroxyl groups at positions $\mathrm{O}-2, \mathrm{O}-3$, and $\mathrm{O}-4$ are in an axial orientation and the substituent at position $\mathrm{C}-1$ is equatorial due to a piperidine ring inversion under acidic conditions such as in the lysosomal environment. In contrast, ring nitrogen substituted DIX derivatives, $\mathbf{5 - 8}$, are found in the typical ${ }^{4} \mathrm{C}_{1}$ conformation (A, Fig. 8). This might be an explanation for the exceptional ligand properties as well as the selectivity of C-1-substituted DIX derivatives, which has been observed previously by others and us for similar alkyl-iminoxylitols [30, 34, 36-40].

We are interested in the synthesis of iminosugar-based glycomimetics as tools for profiling and as ligands for modulating GCase activity. Consequently, we want to develop a simple and convenient approach towards N-modified DIXbased building blocks locked in the ${ }^{1} \mathrm{C}_{4}$ conformation which carry a substituent suitable for further modifications for 


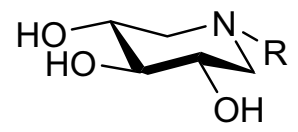

$A:{ }^{4} C_{1}$ conformation

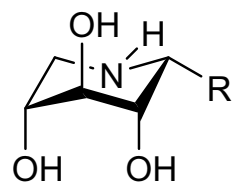

B: ${ }^{1} \mathrm{C}_{4}$ conformation
Fig. 8 Conformations of C-1 modified DIX derivatives

different applications taking advantage of the exceptional ligand properties of this system.

\section{Results and discussion}

For this study, we had to take two considerations into account. We wanted to investigate which modification pattern is best for ligand properties, modification at position $\mathrm{C}-1$ or at the ring nitrogen. In addition, we were looking for a suitable functional group at the terminus of the handle which would allow further functionalisation for different applications, including introduction of reporter groups such as fluorescent dyes or click chemistry features. We decided to introduce either an ester group or an imidazole residue. Both functional groups have been found to be suitable for ligand properties of GCase [34, 36].

For the synthesis of the C-1-modified DIX compounds, 1- $C$-ethenyliminoxylitol derivative 16, which has been synthesized previously by a Staudinger/aza-Wittig/Grignard reaction sequence [40], served as suitable starting material (Scheme 1). Ozonolysis of compound $\mathbf{1 6}$ followed by a Horner-Wadsworth-Emmons reaction employing triethyl phosphonoacetate gave 1-C-(ethyloxycarbonyl-2-ethenyl) iminoxylitol derivative $\mathbf{1 7}$ in $\mathbf{7 8 \%}$ over two steps. The double bond was reduced employing $\mathrm{Pd} / \mathrm{BaSO}_{4}$ as catalyst under hydrogen atmosphere to provide compound $\mathbf{1 8}$ in $45 \%$ which, after the final deprotection under hydrogenolytical conditions, furnished (1R)-1-C-ethyloxycarbonylethyl1,5-dideoxy-1,5-imino-D-xylitol (19) in 72\%. As expected, this compound exhibits the ${ }^{1} \mathrm{C}_{4}$ conformation according to the NMR analysis, coupling constants of protons along the sugar ring exhibit characteristic values in the range of $3-5 \mathrm{~Hz}$ as are typical for this conformation.

For the introduction of the histamine moiety (Scheme 2), imine 18 was protected with a carboxybenzyl group $(\mathrm{Cbz})$ at the ring nitrogen to give compound $\mathbf{2 0}$. The terminal ester group was saponified employing $\mathrm{NaOH}$ to furnish 1- $C$-propionic acid derivative 21, which was used without purification for the coupling step employing histamine dihydrochloride, (1-cyano-2-ethoxy-2-oxoethylidenaminooxy) dimethylaminomorpholinocarbenium hexafluorophosphate (COMU) and $N, N$-diisopropylethylamine (DIEA) as coupling cocktail to give protected ( $1 R$ )-1-C-(imidazo-4-yl) ethylaminocarbonylethyliminoxylitol $\mathbf{2 2}$ in $75 \%$ yield. Final deprotection under hydrogenolytic conditions gave the imidazole-modified iminoxylitol $\mathbf{2 3}$ in a yield of $78 \%$. As expected, also this compound features the ${ }^{1} \mathrm{C}_{4}$ conformation according to the NMR analysis, coupling constants of protons along the sugar ring exhibit characteristic values in the range of 3-5 Hz.

To install the same modification patterns, an ester as well as the imidazole group, at the ring nitrogen, the double bond in protected 1-C-ethenyliminoxylitol 16 was reduced employing $\mathrm{Pd} / \mathrm{BaSO}_{4}$ as catalyst under hydrogen atmosphere (Scheme 3). Under the same reaction conditions, the $\mathrm{N}-\mathrm{Cbz}$ protecting group was cleaved off to give benzyl-protected (1R)-1-C-ethyliminoxylitol $\mathbf{2 4}$ in $81 \%$ yield. Introduction of the methoxycarbonylpentyl group at the ring nitrogen was achieved by employing methyl 6-iodohexanoate and sodium carbonate as base in DMF to give $\mathrm{N}$-alkylated iminoxylitol $\mathbf{2 5}$ in $67 \%$ yield. No formation of a quaternary
Scheme 1<smiles>C=C[C@@H]1[C@@H](OCc2ccccc2)[C@H](OCc2ccccc2)[C@@H](OCc2ccccc2)CN1C(=O)O</smiles>

1) $\mathrm{O}_{3}, \mathrm{CH}_{2} \mathrm{Cl}_{2} / \mathrm{MeOH}$, $-30^{\circ} \mathrm{C}$

2) triethylphosphonoacetate, KOtBu , THF

16<smiles>CCOC(=O)CC[C@H]1NC[C@@H](OCc2ccccc2)[C@H](O)[C@@H]1Cc1ccccc1</smiles><smiles>COCCOCCOCCO</smiles><smiles>CCOC(=O)/C=C/[C@H]1[C@H](O)[C@H](O)[C@@H](Cc2ccccc2)CN1C(=O)OCc1ccccc1</smiles>

17<smiles>CCOC(=O)CC[C@@H]1NC[C@@H](O)[C@H](O)[C@H]1O</smiles>

19 
Scheme 2<smiles>CCOC(=O)CC[C@H]1NC[C@@H](OCc2ccccc2)[C@@H](OCc2ccccc2)[C@@H]1OCc1ccccc1</smiles>

18

20

21

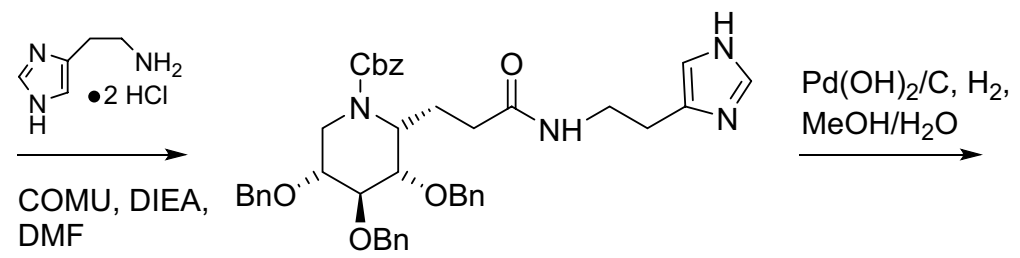

22<smiles>O=C(CC[C@@H]1NC[C@@H](O)[C@H](O)[C@@H]1O)NCCc1c[nH]cn1</smiles>

23

Scheme 3<smiles>C=C[C@@H]1[C@@H](Oc2ccccc2)[C@H](OCc2ccccc2)[C@@H](OC(=O)[O-])CN1C(=O)O</smiles>

16 $\mathrm{Pd} / \mathrm{BaSO}$
$\mathrm{MeOH}$<smiles>CC[C@H]1NC[C@@H](OCc2ccccc2)[C@H](O)[C@@H]1OCc1ccccc1</smiles>

24<smiles>COC(=O)C(I)C(C)I</smiles>
$\mathrm{Na}_{2} \mathrm{CO}_{3}$, DMF<smiles>CC[C@H]1[C@H](O)[C@@H](O)[C@H](OCc2ccccc2)CN1CCCCCC(=O)OC</smiles>

25

$\mathrm{Pd}(\mathrm{OH})_{2} / \mathrm{C}, \mathrm{H}_{2}$, $\mathrm{MeOH} / \mathrm{H}_{2} \mathrm{O}$<smiles>CC[C@H]1[C@@H](O)[C@@H](O)[C@@H](O)CN1CCCCCC(=O)OC</smiles>

26

ammonium ion by double alkylation of the ring nitrogen has been observed during this reaction. Final deprotection of the benzyl groups under hydrogenolytical conditions gave (1R)-1-C-ethyl- $N$-methoxycarbonylpentyliminoxylitol (26) in $88 \%$ yield. Also compounds 24-26 were found in the ${ }^{1} \mathrm{C}_{4}$ conformation exclusively, due to NMR analysis. Likely, the ethyl group at the position $\mathrm{C}-1$ is being responsible for this finding.

The introduction of the imidazole moiety was conducted accordingly to the synthesis of compound $\mathbf{2 3}$ (Scheme 4). Saponification of the methyl ester of compound $\mathbf{2 5}$ followed by coupling of the histamine moiety led to protected imidazole-modified iminosugar derivative 27. Final debenzylation by hydrogenolysis gave (1R)-1-C-ethyl- $N$-(imidazo4-yl)ethylethylaminocarbonylpentyliminoxylitol (28) in $86 \%$ yield. Accordingly, all compounds in this series were also found to adopt the ${ }^{1} \mathrm{C}_{4}$ conformation by NMR analysis. The coupling constants of protons along the sugar ring exhibit characteristic values in the range of $3-5 \mathrm{~Hz}$ as are typical for this conformation.

For the biological evaluation of the synthesized DIX derivatives $\mathbf{1 9}, \mathbf{2 3}, \mathbf{2 6}$, and $\mathbf{2 8}$, we have probed a series of standard glycoside hydrolases, including $\beta$-glucosidase from Agrobacterium sp. (ABG), $\beta$-galactosidase from $E$. coli, Fabrazyme (commercial recombinant human lysosomal $\alpha$-galactosidase), $\alpha$-glucosidase $S$. cerevisiae, and human $\beta$-glucocerebrosidase GCase, to investigate ligand activity as well as selectivity. All compounds were found highly selective inhibitors of $\beta$-glucosidases and showed practically no detectable interaction with $\alpha$-glucosidase (S. cer.), $\beta$-Gal (E. coli), as well as human $\alpha$-Gal (Fabrazyme), respectively, confirming the findings of other groups mentioned above. Both imidazole-modified compounds, 23 ( $K_{\mathrm{i}}$ value $\left.1.1 \mu \mathrm{M}\right)$ as well as $\mathbf{2 8}(4.1 \mu \mathrm{M})$, showed better inhibitory activity for 
Scheme 4<smiles>CC[C@H]1[C@@H](OCc2ccccc2)[C@H](OCc2ccccc2)[C@@H](OCc2ccccc2)CN1CCCCCC(=O)OC</smiles>

Table $1 K_{\mathrm{i}}$ values $[\mu \mathrm{M}]$ of compounds with $\mathrm{ABG}=\beta$-glucosidase $/ \beta$ galactosidase from Agrobacterium sp.; $\beta$-galactosidase from E. coli; Fabrazyme $=$ commercial recombinant human lyso- somal $\alpha$-galactosidase; $\alpha$-glucosidase $S . \quad$ cerevisiae; human $\beta$-glucocerebrosidase Gaucher; N.I. $=$ no inhibition or weak inhibition with estimated $K_{\mathrm{i}}$ values higher than $1 \mathrm{mM}$

\begin{tabular}{|c|c|c|c|c|}
\hline \multirow[t]{2}{*}{ Enzyme } & \multicolumn{4}{|c|}{ Compound } \\
\hline & & HO" & & HO " \\
\hline$\beta$-Glu, ABG & 2.1 & 1.6 & N.I. & N.I. \\
\hline$\beta$-Gal, E. coli & N.I. & N.I. & N.I. & N.I. \\
\hline$\alpha$-Gal, Fabrazyme & N.I. & N.I. & N.I. & N.I. \\
\hline$\alpha$-Glu, S. cer. & N.I. & N.I. & N.I. & N.I. \\
\hline$\beta$-Glu, Gaucher & 5.1 & 1.1 & 57 & 4.1 \\
\hline
\end{tabular}

GCase compared to the ester-modified iminoxylitols $19\left(K_{i}\right.$ value $5.1 \mu \mathrm{M})$ and $26(57 \mu \mathrm{M})$. Concerning our question regarding the modification pattern, we have obtained a very clear picture: 1- $C$-modified iminoxylitols 19 and 23 did not distinguish in their ligand properties between $\beta$-Glu from ABG and GCase with $K_{\mathrm{i}}$ values in the same low $\mu \mathrm{M}$ range. In contrast, the ring nitrogen-modified compounds $\mathbf{2 6}$ and 28 showed excellent selectivity, with $K_{\mathrm{i}}$ values of 57 and $4.1 \mu \mathrm{M}$, respectively, for GCase. No detectable inhibition of $\mathbf{2 6}$ as well as $\mathbf{2 8}$ was found with the other enzymes investigated, including $\beta$-Glu ABG. This increase in selectivity might be explained by the fact that compounds $\mathbf{2 6}$ and $\mathbf{2 8}$ combine the advantages of both features, the ethyl group at position $\mathrm{C}$-1 locking the structure in the ${ }^{1} \mathrm{C}_{4}$ conformation as well as the lipophilic substituents at the ring nitrogen. The former has been implied for favorable ligand properties and the fitting into the active site of GCase. The latter interacts with the lipophilic entrance to the active site of GCase mimicking the ceramide residue of the natural substrate glucosyl ceramide. Compounds $\mathbf{2 6}$ and $\mathbf{2 8}$ will serve as building blocks for further functionalisation as proposed.

\section{Conclusion}

We have investigated which position of substitution at the iminoxylitol scaffold for the introduction of further modifications is favorable, the ring nitrogen or position C-1. Therefore, we have synthesized two compounds in both patterns, one carrying a terminal ester group, compounds $\mathbf{1 9}$ and $\mathbf{2 6}$, and the other presenting an imidazole motif, compounds $\mathbf{2 3}$ and $\mathbf{2 8}$, for further modification. All four compounds were biologically evaluated with a series of standard glycosidases including human lysosomal $\beta$-glucocerebrosidase (GCase). Compounds 19 and 23, with the modification at position C-1 of the DIX scaffold, showed excellent selectivity towards $\beta$-glucosidases; however, both did not discriminate $\beta$-Glu from ABG and human lysosomal GCase, with $K_{\mathrm{i}}$ values found in the low $\mu \mathrm{M}$ range. Compounds $\mathbf{2 6}$ and $\mathbf{2 8}$, carrying the modifications at the ring nitrogen and additionally an ethyl group at position C-1, turned out to interact exclusively with human lysosomal GCase with $K_{\mathrm{i}}$ values of 57 and $4.1 \mu \mathrm{M}$, respectively. No detectable inhibition for any other enzyme included in this study has been observed. Thus, DIX-based scaffolds $\mathbf{2 6}$ and $\mathbf{2 8}$ are excellent building 
blocks for further modifications customized for different applications, such as for ligands to modulate and tools for profiling GCase activity.

\section{Experimental}

Optical rotations were measured at $20^{\circ} \mathrm{C}$ on a Perkin Elmer 341 polarimeter at a wavelength of $589 \mathrm{~nm}$ and a path length of $10 \mathrm{~cm}$. NMR spectra were recorded on a Varian INOVA 500 operating at $499.82 \mathrm{MHz}\left({ }^{1} \mathrm{H}\right)$, and at $125.894 \mathrm{MHz}$ $\left({ }^{13} \mathrm{C}\right)$ or on a Bruker Ultra-shield spectrometer at 300.36 and $75.53 \mathrm{MHz}$, respectively. $\mathrm{CDCl}_{3}$ was employed for protected compounds and methanol- $d_{4}$ or $\mathrm{D}_{2} \mathrm{O}$ for unprotected iminoxylitols. Carbon and hydrogen numbering in NMR spectra was conducted in analogy to carbohydrate nomenclature and clockwise, starting with the pseudo anomeric position carbon as C-1. Chemical shifts are listed in delta employing residual, non-deuterated solvent as the internal standard. Signals were assigned unambiguously by COSY, HSQC, as well as APT analysis. The signals of the protecting groups as well as of the $\mathrm{N}$-substituents were found in the expected regions and are only listed explicitly when overlapping with important spectral features of the respective compound. MALDI-TOF mass spectrometry was performed on a Micromass TofSpec 2E Time-of-Flight Mass Spectrometer. Analytical TLC was performed on precoated aluminum plates silica gel 60 F254 (E. Merck 5554) and detected with UV light (254 nm). For staining, a solution of $9 \mathrm{~g}$ vanillin in a mixture of $950 \mathrm{~cm}^{3} \mathrm{H}_{2} \mathrm{O} / 750 \mathrm{~cm}^{3} \mathrm{EtOH} / 120 \mathrm{~cm}^{3} \mathrm{H}_{2} \mathrm{SO}_{4}$ or ceric ammonium molybdate (100 $\mathrm{g}$ ammonium molybdate $/ 8 \mathrm{~g}$ ceric sulfate in $1 \mathrm{dm}^{3} 10 \% \mathrm{H}_{2} \mathrm{SO}_{4}$ ) was employed followed by heating on a hotplate. For column chromatography, silica gel 60 (230-400 mesh, E. Merck 9385) or silica gel 60 (Acros Organics, AC 24036) were used.

Kinetic studies were performed at $37{ }^{\circ} \mathrm{C}$ in an appropriate buffer using a known concentration of enzyme (specific conditions depicted below). $K_{\mathrm{i}}$ determinations were performed using the corresponding 4-nitrophenyl $\alpha$ - or $\beta$-Dglycopyranoside as substrate. In a typical assay, the enzyme was incubated with different inhibitor concentrations for up to $5 \mathrm{~min}$ before initiating the reaction by the addition of substrate. The initial reaction rate was measured by monitoring the increase in absorbance at $400 \mathrm{~nm}$ for up to $10 \mathrm{~min}$. $K_{\mathrm{i}}$ determinations were performed using at least two different substrate concentrations. For each inhibitor, a range of four-to-six inhibitor concentrations bracketing the $K_{\mathrm{i}}$ value ultimately determined was used for each substrate concentration. Dixon plots ( $1 / v$ vs. [I]) were constructed to validate the use of the competitive inhibition model. The data were then fitted using non-linear regression analysis with Grafit 7.0. Specific assay conditions for each enzyme: Agrobacterium $s p$. $\beta$-glucosidase was expressed and purified recombinantly in E. coli as previously described [43]: $50 \mathrm{mM}$ sodium phosphate buffer (pH 7) using $1.85 \times 10^{-4} \mathrm{mg} / \mathrm{cm}^{3}$ of enzyme $\left(K_{\mathrm{m}}=4.1 \mathrm{mM}\right)[41,42]$; E.coli lac $z \beta$-galactosidase (SigmaAldrich): $50 \mathrm{mM}$ sodium phosphate, $1.0 \mathrm{mM} \mathrm{MgCl} 2(\mathrm{pH}$ 7) using $6.4 \times 10^{-4} \mathrm{mg} / \mathrm{cm}^{3}$ of enzyme $\left(K_{\mathrm{m}}=60 \mu \mathrm{M}\right)$; Fabrazyme (acid $\alpha$-galactosidase, generously gifted by $\mathrm{Dr}$ Lorne Clarke, Department of Medical Genetics, University of British Columbia): $20 \mathrm{mM}$ sodium citrate, $50 \mathrm{mM}$ sodium phosphate, $1.0 \mathrm{mM}$ tetrasodium EDTA, $0.25 \% \mathrm{v} / \mathrm{v}$ Triton $\mathrm{X}-100^{\circledR}$, and $0.25 \% \mathrm{w} / \mathrm{v}$ taurocholic acid buffer $(\mathrm{pH}$ 5.5) using $5 \times 10^{-5} \mathrm{mg} / \mathrm{cm}^{3}$ of enzyme $\left(K_{\mathrm{m}}=0.65 \mathrm{mM}\right) ; S$. cerevisiae $\alpha$-glucosidase (Sigma-Aldrich): $50 \mathrm{mM}$ sodium phosphate buffer ( $\mathrm{pH} 7$ ) using $5 \times 10^{-3} \mathrm{mg} / \mathrm{cm}^{3}$ of enzyme (PNP $\alpha$-Glc, $K_{\mathrm{m}}=0.75 \mathrm{mM}$ ); $\beta$-Glucocerebrosidase (GCase, generously gifted by Dr. Lorne Clarke, Department of Medical Genetics, University of British Columbia): $20 \mathrm{mM}$ citric acid, $50 \mathrm{mM}$ sodium phosphate, $1 \mathrm{mM}$ tetrasodium EDTA, $0.25 \% \mathrm{v} / \mathrm{v}$ Triton X-100, and $0.25 \% \mathrm{w} / \mathrm{v}$ taurocholic acid ( $\mathrm{pH}$ 7.0) $\left(K_{\mathrm{m}}=1.1 \mathrm{mM}\right)$.

(1R)-2,3,4-Tri-O-benzyl- $N$-(benzyloxycarbonyl)-1-C-(ethyloxycarbonylethenyl)-1,5-dideoxy-1,5-imino-D-xylitol (17, $\mathrm{C}_{39} \mathrm{H}_{41} \mathrm{NO}_{7}$ ) Compound 16 [40] (550 mg, $0.98 \mathrm{mmol}$ ) was dissolved in $100 \mathrm{~cm}^{3} \mathrm{CH}_{2} \mathrm{Cl}_{2} / \mathrm{MeOH}(1 / 1, \mathrm{v} / \mathrm{v})$ and stirred under an atmosphere of ozone at $-30{ }^{\circ} \mathrm{C}$ until no starting material was detected on TLC (cyclohexane/EtOAc $=2 / 1$, $\mathrm{v} / \mathrm{v}) . \mathrm{N}_{2}$ was bubbled through the reaction mixture to remove ozone traces and $200 \mathrm{~mm}^{3}$ dimethylsulfide was added to the reaction mixture, which was stirred for $45 \mathrm{~min}$, followed by concentration under reduced pressure. The resulting colorless oil was added dropwise to a prepared solution of $330 \mathrm{mg}$ $\mathrm{KO} t \mathrm{Bu}(2.90 \mathrm{mmol}, 3 \mathrm{eq})$ and $580 \mathrm{~mm}^{3}$ triethylphosphonoacetate $(2.90 \mathrm{mmol}, 3 \mathrm{eq})$ in $50 \mathrm{~cm}^{3}$ THF. Upon consumption of the starting material (detected by TLC: cyclohexane/ EtOAc $=2 / 1, \mathrm{v} / \mathrm{v}), \mathrm{CH}_{2} \mathrm{Cl}_{2}$ was added and extracted with $2 \mathrm{~N} \mathrm{HCl}$ and satd. $\mathrm{NaHCO}_{3}$ solution. The organic phase was dried over $\mathrm{Na}_{2} \mathrm{SO}_{4}$ and concentrated under reduced pressure. Purification utilizing silica gel chromatography (cyclohexane $/$ EtOAc $=10 / 1$, v/v) gave compound $17(500 \mathrm{mg})$ with a yield of $78 \%$ as colorless oil. $R_{f}=0.55$ (cyclohexane/EtOAc $=2 / 1, \mathrm{v} / \mathrm{v})$. MS: $m / z$ calcd. for $\mathrm{C}_{39} \mathrm{H}_{41} \mathrm{NO}_{7} \mathrm{Na}$ 658.2781, found 658.2762. Due to two pronounced rotameric populations of the $\mathrm{N}-\mathrm{Cbz}$ group as well as a mixture of $\mathrm{E} / \mathrm{Z}$ isomers of the double bond, signal splitting as well as signal overlapping in the respective NMR spectra have been observed leading to poor resolution. The respective peaks, however, are observed in the expected region.

(1R)-2,3,4-Tri-O-benzyl-1-C-(ethyloxycarbonylethyl)-1,5dideoxy-1,5-imino-D-xylitol $\left(18, \mathrm{C}_{31} \mathrm{H}_{37} \mathrm{NO}_{5}\right)$ Compound 17 (1.4 g, $2.2 \mathrm{mmol}$ ) was dissolved in $30 \mathrm{~cm}^{3} \mathrm{MeOH}, \mathrm{Pd} / \mathrm{BaSO}_{4}$ was added, and the reaction mixture stirred under hydrogen atmosphere until the starting material was not detectable 
by TLC $($ cyclohexane/EtOAc $=2 / 1, \mathrm{v} / \mathrm{v})$. The reaction mixture was filtered and concentrated under reduced pressure. Compound $18(500 \mathrm{mg})$ was purified utilizing silica gel chromatography (cyclohexane/EtOAc $=1 / 1, \mathrm{v} / \mathrm{v}$ ) and isolated in $45 \%$ yield as colorless oil. $R_{f}=0.10$ (cyclohexane/EtOAc $=1 / 1, \mathrm{v} / \mathrm{v})$; MS: $m / z$ calcd. for $\mathrm{C}_{31} \mathrm{H}_{37} \mathrm{NO}_{5} \mathrm{Na}$ 526.2569, found 526.2639; ${ }^{1} \mathrm{H}$ NMR $\left(300 \mathrm{MHz}, \mathrm{CDCl}_{3}\right)$ : $\delta=7.32-7.10(\mathrm{~m}, 15 \mathrm{H}, \mathrm{Ph}), 4.53-4.40\left(\mathrm{~m}, 6 \mathrm{H}, \mathrm{CH}_{2} \mathrm{Ph}\right)$, 4.05 (q, 2H, H-9), $3.68\left(\mathrm{dd}, J_{3,2}=5.7 \mathrm{~Hz}, J_{3,4}=5.5 \mathrm{~Hz}\right.$, $1 \mathrm{H}, \mathrm{H}-3$ ), 3.33 (dd, $\left.J_{2,1}=4.5 \mathrm{~Hz}, 1 \mathrm{H}, \mathrm{H}-2\right), 3.32$ (ddd, $\left.J_{4,5}=5.6 \mathrm{~Hz}, 1 \mathrm{H}, \mathrm{H}-4\right), 2.96-2.87$ (m, 2H, H-1, H-5e), 2.81 (dd, $\left.J_{5 \mathrm{a}, 5 \mathrm{e}}=13.5 \mathrm{~Hz}, 1 \mathrm{H}, \mathrm{H}-5 \mathrm{a}\right), 2.40-2.19(\mathrm{~m}, 2 \mathrm{H}, \mathrm{H}-7)$, 1.85-1.75 (m, 2H, H-6), 1.17 (t, 3H, H-10) ppm; ${ }^{13} \mathrm{C} \mathrm{NMR}$ $\left(75.5 \mathrm{MHz}, \mathrm{CDCl}_{3}\right): \delta=173.9(\mathrm{C}-8), 138.7,138.6,138,5$ $\left(3 \mathrm{C}, 3 \mathrm{xC}_{\mathrm{q}}\right), 128.5-127.7(\mathrm{Ph}), 78.2(\mathrm{C}-4), 77.4(\mathrm{C}-2), 76.5$ (C-3), 73.9, 72.4, $72.0\left(3 \mathrm{C}, 3 \times \mathrm{CH}_{2} \mathrm{Ph}\right), 60.4(\mathrm{C}-9), 54.5$ (C-1), 44.6 (C-5), 31.5 (C-7), 24.0 (C-6), 14.4 (C-10) ppm.

(1R)-1-C-(Ethyloxycarbonylethyl)-1,5-dideoxy-1,5-imino-d-xylitol (19, $\left.\mathrm{C}_{10} \mathrm{H}_{19} \mathrm{NO}_{5}\right)$ Compound $18(150 \mathrm{mg}$, $0.30 \mathrm{mmol})$ was dissolved in $\mathrm{MeOH} / \mathrm{H}_{2} \mathrm{O}(1 / 1, \mathrm{v} / \mathrm{v})$ and $\mathrm{Pd}(\mathrm{OH})_{2}$ on activated charcoal was added to the solution. The reaction mixture was stirred under hydrogen atmosphere until the starting material was consumed TLC (cyclohexane/ EtOAc $=1 / 2, v / v)$. The reaction mixture was filtered, concentrated under reduced pressure and the obtained oil was purified utilizing silica gel chromatography $\left(\mathrm{CHCl}_{3} / \mathrm{MeOH} /\right.$ concd $\left.\mathrm{NH}_{4} \mathrm{OH}=3 / 1 / 0.01, \mathrm{v} / \mathrm{v} / \mathrm{v}\right)$. Compound $19(50 \mathrm{mg})$ was obtained in $72 \%$ yield as colorless oil. $R_{f}=0.80\left(\mathrm{CHCl}_{3} /\right.$ $\mathrm{MeOH} /$ concd $\mathrm{NH}_{4} \mathrm{OH}=1 / 1 / 0.25$, v/v/v); MS: $m / z$ calcd. for $\mathrm{C}_{10} \mathrm{H}_{19} \mathrm{NO}_{5} \mathrm{Na} 256.1161$, found 256.1188; $[a]_{D}^{20}=-13.8$ $\left(c=1.2, \mathrm{H}_{2} \mathrm{O}\right) ;{ }^{1} \mathrm{H}$ NMR $\left(300 \mathrm{MHz}, \mathrm{D}_{2} \mathrm{O}\right): \delta=4.10(\mathrm{q}, 2 \mathrm{H}$, H-9), 3.99-3.94 (m, 2H, H-3, H-4), 3.88 (dd, $J_{1,2}=3.6 \mathrm{~Hz}$, $\left.J_{2,3}=4.6 \mathrm{~Hz}, 1 \mathrm{H}, \mathrm{H}-2\right), 3.46\left(\mathrm{ddd}, J_{1,2}=1.3 \mathrm{~Hz}, 1 \mathrm{H}, \mathrm{H}-1\right.$ ), $3.36\left(\mathrm{dd}, J_{5 \mathrm{a}, 4}=2.2 \mathrm{~Hz}, J_{5 \mathrm{e}, 5 \mathrm{a}}=13.8 \mathrm{~Hz}, 1 \mathrm{H}, \mathrm{H}-5 \mathrm{a}\right), 3.24(\mathrm{dd}$, $\left.J_{5 \mathrm{e}, 4}=1.6 \mathrm{~Hz}, 1 \mathrm{H}, \mathrm{H}-5 \mathrm{a}\right), 2.58-2.40(\mathrm{~m}, 2 \mathrm{H}, \mathrm{H}-7), 2.08-1.91$ (m, 2H, H-6), 1.18 (t, 3H, H-10) ppm; ${ }^{13} \mathrm{C}$ NMR $(75.5 \mathrm{MHz}$, $\left.\mathrm{D}_{2} \mathrm{O}\right): \delta=174.9(\mathrm{C}-8), 67.5(\mathrm{C}-2), 67.0(\mathrm{C}-3), 66.1(\mathrm{C}-4)$, 62.1 (C-9), 54.3 (C-1), 45.5 (C-5), 29.4 (C-7), 23.0 (C-6), 13.4 (C-10) ppm.

(1R)-2,3,4-Tri-O-benzyl- $N$-(benzyloxycarbonyl)-1-C-(ethyloxycarbonylethyl)-1,5-dideoxy-1,5-imino-D-xylitol (20, $\left.\mathrm{C}_{39} \mathrm{H}_{43} \mathrm{NO}_{7}\right)$ Compound $18(750 \mathrm{mg}, 1.40 \mathrm{mmol})$ was dissolved in $20 \mathrm{~cm}^{3} \mathrm{MeOH}$ and $480 \mathrm{~mm}^{3} \mathrm{Et}_{3} \mathrm{~N}(3.40 \mathrm{mmol}$, $2.4 \mathrm{eq}) . \mathrm{CbzCl}\left(250 \mathrm{~mm}^{3}, 1.70 \mathrm{mmol}, 1.2 \mathrm{eq}\right)$ was added and the reaction mixture was stirred at ambient temperature. Upon consumption of the starting material (detected by TLC: cyclohexane/EtOAc $=1 / 1, \mathrm{v} / \mathrm{v}$ ), the reaction mixture was concentrated under reduced pressure, dissolved in $\mathrm{CH}_{2} \mathrm{Cl}_{2}$, and extracted with $2 \mathrm{~N} \mathrm{HCl}$ and sat. $\mathrm{NaHCO}_{3}$ solution. The organic layer was dried over $\mathrm{Na}_{2} \mathrm{SO}_{4}$ and concentrated under reduced pressure. Compound $\mathbf{2 0}(270 \mathrm{mg})$ was obtained after purification utilizing silica gel chromatography (cyclohexane/EtOAc $=10 / 1, \mathrm{v} / \mathrm{v})$ in $24 \%$ yield as colorless oil. $R_{f}=0.45($ cyclohexane $/ \mathrm{EtOAc}=3 / 1, \mathrm{v} / \mathrm{v})$; ${ }^{1} \mathrm{H}$ NMR $\left(300 \mathrm{MHz}, \mathrm{CDCl}_{3}\right): \delta=7.29-7.12(\mathrm{~m}, 20 \mathrm{H}, \mathrm{Ph})$, 5.03-4.94 (m, 2H, CH $\left.\mathrm{C}_{2} \mathrm{Cbz}\right), 4.80-4.74\left(\mathrm{~m}, 2 \mathrm{H}, \mathrm{CH}_{2} \mathrm{Ph}\right)$, 4.65-4.50 (m, 5H, 2xCH $\left.\mathrm{Xh}_{2} \mathrm{Ph}-1\right), 4.36-4.26(\mathrm{~m}, 1 \mathrm{H}, \mathrm{H}-1$, H-5e), 4.09-3.90 (m, 2H, H-9, H-5e), 3.58 (dd, $J_{3,2}=9.0 \mathrm{~Hz}$, $\left.J_{3,4}=9.2 \mathrm{~Hz}, 1 \mathrm{H}, \mathrm{H}-3\right), 3.42\left(\mathrm{dd}, J_{2,1}=6.1 \mathrm{~Hz}, 1 \mathrm{H}, \mathrm{H}-2\right)$, 3.32 (ddd, $\left.J_{4,5}=5.5 \mathrm{~Hz}, 1 \mathrm{H}, \mathrm{H}-4\right), 2.65\left(\mathrm{dd}, J_{5 \mathrm{a}, 5 \mathrm{e}}=13.1 \mathrm{~Hz}\right.$, 1H, H-5a), 2.22-2.07 (m, 2H, H-7), 1.93-1.72 (m, 2H, H-6), 1.12 (t, 3H, H-10) ppm; ${ }^{13} \mathrm{C}$ NMR $\left(75.5 \mathrm{MHz}, \mathrm{CDCl}_{3}\right)$ : $\delta=173.1(\mathrm{~d}, \mathrm{C}-8), 155.6(\mathrm{~d}, \mathrm{Cbz}), 138.9,138.2,136.4$ $\left(\mathrm{C}_{\mathrm{q}}-\mathrm{Ph}\right), 128.7-127.0(\mathrm{Ph}), 82.0(\mathrm{~d}, \mathrm{C}-3), 79.6$ (d, C-2), 78.2 (C-4), 75.8, 73.2, $72.8\left(\mathrm{~d}, \mathrm{CH}_{2} \mathrm{Ph}\right), 67.7$ (d, $\left.\mathrm{CH}_{2} \mathrm{Cbz}\right), 60.5$ (d, C-9), 52.7 (d, C-1), 40.9 (d, C-5), 30.7 (C-7), 19.9 (d, C-6), 14.3 (C-10) ppm. Due to two pronounced rotameric populations (20) of the $\mathrm{N}$-Cbz group, signal splitting in the respective NMR spectra has been observed leading to somehow poor resolution of NMR spectra.

(1R)-2,3,4-Tri-O-benzyl-N-(benzyloxycarbonyl)-1-C-(carboxyethyl)-1,5-dideoxy-1,5-imino-D-xylitol $\left(21, \mathrm{C}_{37} \mathrm{H}_{39} \mathrm{NO}_{7}\right)$ Compound $20(220 \mathrm{mg}, 0.35 \mathrm{mmol})$ was dissolved in $20 \mathrm{~cm}^{3}$ dioxane/ $\mathrm{H}_{2} \mathrm{O}(1 / 1, \mathrm{v} / \mathrm{v})$ and $1 \mathrm{~cm}^{3}$ of a $3 \mathrm{M} \mathrm{NaOH}$ solution was added dropwise. After consumption of the starting material (detected by TLC: cyclohexane/EtOAc $=3 / 1$, $\mathrm{v} / \mathrm{v}$ ), the reaction mixture was acidified with $2 \mathrm{~N} \mathrm{HCl}$ and extracted with EtOAc. The combined organic layers were dried over $\mathrm{Na}_{2} \mathrm{SO}_{4}$ and concentrated under reduced pressure. Compound 21 (230 mg) was obtained as slightly yellow oil containing minor amounts of impurities and has been employed for the next step without further purification. $R_{f}=0.60\left(\right.$ EtOAc); ${ }^{1} \mathrm{H}$ NMR $\left(300 \mathrm{MHz}, \mathrm{MeOH}-d_{4}\right)$ : $\delta=7.27-7.08(\mathrm{~m}, 20 \mathrm{H}, \mathrm{Ph}), 5.02-4.90\left(\mathrm{~m}, 2 \mathrm{H}, \mathrm{CH}_{2} \mathrm{Cbz}\right)$, 4.81-4.72 (m, $\left.2 \mathrm{H}, \mathrm{CH}_{2} \mathrm{Ph}\right), 4.57-4.35\left(\mathrm{~m}, 5 \mathrm{H}, 2 \mathrm{xCH}_{2} \mathrm{Ph}\right.$, $\mathrm{H}-1), 4.19\left(\mathrm{dd}, J_{5 \mathrm{e}, 4}=5.2 \mathrm{~Hz}, J_{5 \mathrm{e}, 5 \mathrm{a}}=13.3 \mathrm{~Hz}, 1 \mathrm{H}, \mathrm{H}-5 \mathrm{e}\right)$, 4.03 (dd, $1 \mathrm{H}, \mathrm{H}-5 \mathrm{a}), 3.51$ (dd, $J_{3,2}=8.5 \mathrm{~Hz}, J_{3,4}=9.1 \mathrm{~Hz}, 1 \mathrm{H}$, H-3), 3.35-3.18 (m, 2H, H-2, H-4), 2.18-1.63 (m, 4H, H-6, $\mathrm{H}-7) \mathrm{ppm} ;{ }^{13} \mathrm{C}$ NMR $\left(75.5 \mathrm{MHz}, \mathrm{CDCl}_{3}\right): \delta=179.1$ (d, C-8), 155.7 (d, Cbz), 138.9, 138.1, $136.5\left(\mathrm{C}_{\mathrm{q}}-\mathrm{Ph}\right), 128.7-127.7$ (Ph), 82.1 (d, C-3), 79.9 (d, C-2), 78.3 (C-4), 75.8, 73.3, 72.9 $\left(\mathrm{CH}_{2}-\mathrm{Ph}\right), 67.7$ (d, $\left.\mathrm{CH}_{2}-\mathrm{Cbz}\right), 52.8$ (d, C-1), 40.8 (d, C-5), 30.7 (C-7), 19.7 (d, C-6) ppm. Due to two pronounced rotameric populations (21) of the $N$-Cbz group, signal splitting in the respective NMR spectra has been observed.

(1R)-2,3,4-Tri-O-benzyl- $N$-(benzyloxycarbonyl)-1-C-[(imidazo4-yl)ethylaminocarbonylethyl]-1,5-dideoxy-1,5-imino-D-xylitol (22, $\mathrm{C}_{42} \mathrm{H}_{46} \mathrm{~N}_{4} \mathrm{O}_{6}$ ) Compound 21 (340 mg, $0.57 \mathrm{mmol}$ ) was dissolved in $20 \mathrm{~cm}^{3}$ DMF. COMU (490 mg, $1.14 \mathrm{mmol}$, 2 eq) and $400 \mathrm{~mm}^{3}$ DIEA ( $\left.2.33 \mathrm{mmol}, 4 \mathrm{eq}\right)$ were added, and the reaction mixture was stirred for $30 \mathrm{~min}$ at ambient temperature. Histamine dihydrochloride $(160 \mathrm{mg}$, 
$0.86 \mathrm{mmol}, 1.5 \mathrm{eq}$ ) was added and the reaction mixture was stirred until the starting material was consumed, TLC $(\mathrm{EtOAc} / \mathrm{MeOH}=10 / 1, \mathrm{v} / \mathrm{v})$. The reaction mixture was concentrated under reduced pressure and purified by silica gel chromatography $(\mathrm{EtOAc} / \mathrm{MeOH}=10 / 1, \mathrm{v} / \mathrm{v})$ to give compound $22(300 \mathrm{mg})$ in $75 \%$ yield. $R_{f}=0.60\left(\mathrm{CHCl}_{3} /\right.$ $\mathrm{MeOH} /$ concd. $\mathrm{NH}_{4} \mathrm{OH}=6 / 1 / 0.01$, v/v/v); MS: $\mathrm{m} / \mathrm{z}$ calcd. for $\mathrm{C}_{42} \mathrm{H}_{46} \mathrm{~N}_{2} \mathrm{O}_{6} \mathrm{Na}$ 725.3315, found 725.3347. Due to two pronounced rotameric populations (22) of the $\mathrm{N}-\mathrm{Cbz}$ group, signal splitting in the respective NMR spectra has been observed leading to poor resolution of the NMR spectra.

(1R)-1-C-[(Imidazo-4-yl)ethylaminocarbonylethyl]-1,5-dideoxy-1,5-imino-D-xylitol $\left(23, \mathrm{C}_{13} \mathrm{H}_{22} \mathrm{~N}_{4} \mathrm{O}_{4}\right)$ Compound 22 ( $300 \mathrm{mg}, 0.43 \mathrm{mmol}$ ) was dissolved in $15 \mathrm{~cm}^{3} \mathrm{MeOH} / \mathrm{H}_{2} \mathrm{O}$ $(1 / 1, v / v), \mathrm{Pd}(\mathrm{OH})_{2}$ on activated charcoal was added and the reaction mixture was stirred under hydrogen atmosphere. Upon consumption of the starting material (detected by TLC: $\mathrm{CHCl}_{3} / \mathrm{MeOH} /$ concd $\mathrm{NH}_{4} \mathrm{OH}=6 / 1 / 0.01$, v/v/v), the reaction mixture was filtered and concentrated under reduced pressure. After purification by silica gel chromatography $\left(\mathrm{CHCl}_{3} / \mathrm{MeOH} /\right.$ concd $\mathrm{NH}_{4} \mathrm{OH}=3 / 1 / 0.25$, v/v/v) compound $23(100 \mathrm{mg})$ was obtained as colorless oil in $78 \%$ yield. $R_{f}=0.50\left(\mathrm{CHCl}_{3} / \mathrm{MeOH} /\right.$ concd $\mathrm{NH}_{4} \mathrm{OH}=1 / 1 / 0.25$, $\mathrm{v} / \mathrm{v} / \mathrm{v}$ ); MS: $\mathrm{m} / z$ calcd. for $\mathrm{C}_{13} \mathrm{H}_{22} \mathrm{~N}_{4} \mathrm{O}_{4} \mathrm{Na} 321.1539$, found $321.1567 ;[a]_{D}^{20}=-6.5\left(c=1, \mathrm{H}_{2} \mathrm{O}\right) ;{ }^{1} \mathrm{H} \mathrm{NMR}(300 \mathrm{MHz}$, $\mathrm{D}_{2} \mathrm{O}$ ): $\delta=7.83$ (s, $1 \mathrm{H}, \mathrm{H}-13$ ), 6.92 (s, $\left.1 \mathrm{H}, \mathrm{H}-12\right), 3.77$ (ddd, $\left.J_{3,4}=4.8 \mathrm{~Hz}, J_{3,2}=5.2 \mathrm{~Hz}, 1 \mathrm{H}, \mathrm{H}-3\right), 3.75\left(\mathrm{dd}, J_{4,5 \mathrm{e}}=3.8 \mathrm{~Hz}\right.$, $\left.J_{4,5 \mathrm{a}}=4.6 \mathrm{~Hz}, 1 \mathrm{H}, \mathrm{H}-4\right), 3.69\left(\mathrm{dd}, J_{1,2}=3.2 \mathrm{~Hz}, 1 \mathrm{H}, \mathrm{H}-2\right)$, 3.36 (t, 2H, H-9), 3.13 (ddd, 1H, H-1), 3.21 (dd, 1H, H-5e), $2.97\left(\mathrm{dd}, J_{5 \mathrm{e}, 5 \mathrm{a}}=13.6 \mathrm{~Hz}, 1 \mathrm{H}, \mathrm{H}-5 \mathrm{a}\right), 2.72(\mathrm{t}, 2 \mathrm{H}, \mathrm{H}-10)$, 2.22 (t, 2H, H-7), 1.89-1.70 (m, 2H, H-6) ppm; ${ }^{13} \mathrm{C}$ NMR (75.5 MHz, $\left.\mathrm{D}_{2} \mathrm{O}\right): \delta=175.1(\mathrm{C}-8), 135.1(\mathrm{C}-13), 133.6$ (C-11), 116.8 (C-12), 68.9 (2C, C-2, C-3), 67.0 (C-4), 54.6 (C-1), 44.8 (C-5), 38.7 (C-9), 31.7 (C-7), 25.4 (C-10), 23.3 (C-6) ppm.

(1R)-2,3,4-Tri-O-benzyl-1-C-ethyl-1,5-dideoxy-1,5-imino-D-xylitol (24, $\mathrm{C}_{28} \mathrm{H}_{33} \mathrm{NO}_{3}$ ) Compound 16 [40] (1.2 g, $2.13 \mathrm{mmol}$ ) was dissolved in $20 \mathrm{~cm}^{3} \mathrm{MeOH} . \mathrm{Pd} / \mathrm{BaSO}_{4}$ was added and the reaction mixture was stirred under hydrogen atmosphere. Upon consumption of the starting material (detected by TLC: cyclohexane/EtOAc $=3 / 1, \mathrm{v} / \mathrm{v}$ ) the reaction mixture was filtered and concentrated under reduced pressure. Compound $\mathbf{2 4}(740 \mathrm{mg})$ was obtained with a yield of $81 \%$ as colorless oil. $R_{f}=0.2$ (cyclohexane/EtOAc $=3 / 1$, $\mathrm{v} / \mathrm{v}) ;[a]_{D}^{20}=-1.1\left(c=1.0, \mathrm{CHCl}_{3}\right) ;{ }^{1} \mathrm{H} \mathrm{NMR}(300 \mathrm{MHz}$, $\left.\mathrm{CDCl}_{3}\right): \delta=7.35-7.07(\mathrm{~m}, 15 \mathrm{H}, \mathrm{Ph}), 4.65-4.35(\mathrm{~m}, 6 \mathrm{H}$, $\mathrm{CH}_{2} \mathrm{Ph}$ ), 3.67 (dd, $\left.J_{3,4=3,2}=5.7 \mathrm{~Hz}, 1 \mathrm{H}, \mathrm{H}-3\right), 3.38-3.23$ (m, $2 \mathrm{H}, \mathrm{H}-2, \mathrm{H}-4), 2.91\left(\mathrm{dd}, J_{5 \mathrm{e}, 4}=4.1 \mathrm{~Hz}, J_{5 \mathrm{e}, 5 \mathrm{a}}=13.4 \mathrm{~Hz}, 1 \mathrm{H}\right.$, $\mathrm{H}-5 \mathrm{e}), 2.89$ (dd, $\left.J_{5 \mathrm{a}, 4}=5.5 \mathrm{~Hz}, 1 \mathrm{H}, \mathrm{H}-5 \mathrm{a}\right), 2.83-2.76(\mathrm{~m}$, $\left.J_{1,2}=3.9 \mathrm{~Hz}, 1 \mathrm{H}, \mathrm{H}-1\right), 1.55-1.42(\mathrm{~m}, 2 \mathrm{H}, \mathrm{H}-6), 0.81(\mathrm{t}, 3 \mathrm{H}$, $\mathrm{H}-7) \mathrm{ppm} ;{ }^{13} \mathrm{C}$ NMR $\left(75.5 \mathrm{MHz}, \mathrm{CDCl}_{3}\right): \delta=138.7\left(3 \mathrm{x} \mathrm{C}_{\mathrm{q}}\right.$ ),
128.4-127.6 (Ph), 78.1 (C-2), 76.9 (C-3), 76.6 (C-4), 73.8, 72.2, 71.9 (3C, 3x $\left.\mathrm{CH}_{2}-\mathrm{Ph}\right), 56.5$ (C-1), 44.4 (C-5), 21.2 (C-6), 10.8 (C-7) ppm.

(1R)-2,3,4-Tri-O-benzyl-1-C-ethyl- $\mathrm{N}$-(methyloxycarbonylpentyl)-1,5-dideoxy-1,5-imino-D-xylitol $\left(25, \mathrm{C}_{35} \mathrm{H}_{45} \mathrm{NO}_{5}\right)$ Compound $24(740 \mathrm{mg}, 1.72 \mathrm{mmol})$ was dissolved in $20 \mathrm{~cm}^{3}$ DMF. 6-Iodohexylmethylester (660 mg, $2.60 \mathrm{mmol}, 1.5 \mathrm{eq})$ and $545 \mathrm{mg} \mathrm{Na} \mathrm{CO}_{3}(5.15 \mathrm{mmol}, 3 \mathrm{eq})$ were added and the reaction mixture was stirred at $60{ }^{\circ} \mathrm{C}$. Upon consumption of the starting material (detected by TLC: cyclohexane/ EtOAc $=2 / 1, v / v$ ), the reaction mixture was concentrated under reduced pressure, dissolved in $\mathrm{CH}_{2} \mathrm{Cl}_{2}$, and extracted with $2 \mathrm{~N} \mathrm{HCl}$ and satd. $\mathrm{NaHCO}_{3}$ solution. The organic layer was dried over $\mathrm{Na}_{2} \mathrm{SO}_{4}$ and concentrated under reduced pressure. Purification by silica gel chromatography gave compound $25(640 \mathrm{mg})$ in a yield of $67 \%$ as colorless oil. $R_{f}=0.55($ cyclohexane/EtOAc $=2 / 1, \mathrm{v} / \mathrm{v}) ;[a]_{D}^{20}=+12.7$ $\left(c=1.1, \mathrm{CHCl}_{3}\right) ; \mathrm{MS}: \mathrm{m} / z$ calcd. for $\mathrm{C}_{35} \mathrm{H}_{45} \mathrm{NO}_{5} \mathrm{Na}$ 582.3195, found 582.3217; ${ }^{1} \mathrm{H}$ NMR (300 $\left.\mathrm{MHz}, \mathrm{CDCl}_{3}\right)$ : $\delta=7.29-7.16(\mathrm{~m}, 15 \mathrm{H}, \mathrm{Ph}), 4.80,4.74\left(2 \mathrm{xd}, 2 \mathrm{H}, \mathrm{CH}_{2} \mathrm{Ph}\right)$, 4.66-4.53 (m, 4H, $\mathrm{CH}_{2} \mathrm{Ph}$ ), 3.59 (s, 3H, H-14), 3.56-3.43 $(\mathrm{m}, 3 \mathrm{H}, \mathrm{H}-2, \mathrm{H}-3, \mathrm{H}-4), 2.78-2.61\left(\mathrm{~m}, J_{1,2}=3.6 \mathrm{~Hz}\right.$, $\left.J_{5 \mathrm{e}, 4}=4.4 \mathrm{~Hz}, J_{5 \mathrm{e}, 5 \mathrm{a}}=12.9 \mathrm{~Hz}, 2 \mathrm{H}, \mathrm{H}-1, \mathrm{H}-5 \mathrm{e}\right), 2.52-2.34$ $\left(\mathrm{m}, J_{5 \mathrm{a}, 4}=5.5 \mathrm{~Hz}, 3 \mathrm{H}, \mathrm{H}-5 \mathrm{a}, \mathrm{H}-8\right), 2.22$ (t, 2H, H-12), 1.631.35 (m, 4H, H-6, H-11), 1.29-1.16 (m, 4H, H-9, H-10), 0.87 (t, 3H, H-7) ppm; ${ }^{13} \mathrm{C}$ NMR (75.5 $\left.\mathrm{MHz}, \mathrm{CDCl}_{3}\right)$ : $\delta=174.3(\mathrm{C}-13), 139.2,138.8,138.7$ (3C, 3x C $), 128.4-$ $127.4(\mathrm{Ph}), 83.2(\mathrm{C}-4), 80.6(\mathrm{C}-2), 78.3(\mathrm{C}-3), 75.5,73.1$, 72.8 (3x $\left.\mathrm{CH}_{2} \mathrm{Ph}\right), 61.6(\mathrm{C}-1), 54.2$ (C-8), 51.5 (C-14), 48.5 (C-5), 34.2 (C-12), 28.4 (C-9), 26.7 (C-10), 24.9 (C-11), 16.5 (C-6), 13.5 (C-7) ppm.

(1R)-1-C-Ethyl- $N$-(methyloxycarbonylpentyl)-1,5dideoxy-1,5-imino-D-xylitol (26, $\left.\mathrm{C}_{14} \mathrm{H}_{27} \mathrm{NO}_{5}\right)$ Compound 25 (350 mg, $0.6 \mathrm{mmol}, 1 \mathrm{eq}$ ) was dissolved in $10 \mathrm{~cm}^{3} \mathrm{MeOH} /$ $\mathrm{H}_{2} \mathrm{O}(1 / 1, \mathrm{v} / \mathrm{v}), \mathrm{Pd}(\mathrm{OH})_{2} / \mathrm{C}$ was added and the reaction mixture was stirred under hydrogen atmosphere at ambient pressure. Upon consumption of the starting material (detected by TLC, eluent: $\mathrm{CHCl}_{3} / \mathrm{MeOH} /$ concd. $\mathrm{NH}_{4} \mathrm{OH}=3 / 1 / 0.01$, $\mathrm{v} / \mathrm{v} / \mathrm{v})$, the reaction mixture was filtered, concentrated under reduced pressure, and purified by silica gel chromatography $\left(\mathrm{CHCl}_{3} / \mathrm{MeOH} /\right.$ concd. $\mathrm{NH}_{4} \mathrm{OH}=10 / 1 / 0.01$, v/v/v) which gave compound $26(160 \mathrm{mg})$ in a yield of $88 \%$ as colorless oil. $R_{f}=0.66\left(\mathrm{CHCl}_{3} / \mathrm{MeOH} /\right.$ concd. $\mathrm{NH}_{4} \mathrm{OH}=3 / 1 / 0.01$, v/v/v); MS: $m / z$ calcd. for $\mathrm{C}_{14} \mathrm{H}_{27} \mathrm{NO}_{5} \mathrm{Na} 312.1787$, found $312.1845 ;[a]_{D}^{20}=+7.4(c=1.0, \mathrm{MeOH}) ;{ }^{1} \mathrm{H} \mathrm{NMR}$ $\left(300 \mathrm{MHz}, \mathrm{MeOH}-d_{4}\right): \delta=4.01-4.00(\mathrm{~m}, 2 \mathrm{H}, \mathrm{H}-3, \mathrm{H}-4)$, $3.96-3.94\left(\mathrm{dd}, J_{1,2}=3.6 \mathrm{~Hz}, J_{2,3}=4.0 \mathrm{~Hz}, 1 \mathrm{H}, \mathrm{H}-2\right), 3.69(\mathrm{~s}$, $3 \mathrm{H}, \mathrm{H}-14$ ), 3.51 (bdd, $J_{5 \mathrm{e}, 4}=1.2 \mathrm{~Hz}, J_{5 \mathrm{e}, 5 \mathrm{a}}=12.8 \mathrm{~Hz}, 1 \mathrm{H}$, H-5e), 3.41-3.32 (m, $J_{5 \mathrm{a}, 4}=3.3 \mathrm{~Hz}, 2 \mathrm{H}, \mathrm{H}-1, \mathrm{H}-5 \mathrm{a}$ ), 3.23 (q, 2H, H-8), 2.41 (t, 2H, H-12), 2.00-1.89 (m, 2H, H-6), 1.82 1.67 (m, 4H, H-9, H-11), 1.50-1.40 (m, 2H, H-10), 1.06 (t, 
$3 \mathrm{H}, \mathrm{H}-7) \mathrm{ppm} ;{ }^{13} \mathrm{C} \mathrm{NMR}\left(75.5 \mathrm{MHz}, \mathrm{MeOH}-d_{4}\right): \delta=175.7$ (C-13), 69.4 (C-4), 69.2 (C-3, C-2), 63.7 (C-1), 54.3 (C-5), 53.7 (C-8), 52.1 (C-14), 34.5 (C-12), 27.2 (C-10), 25.5 (C-11), 23.4 (C-9), 19.8 (C-6), 10.3 (C-7) ppm.

(1R)-2,3,4-Tri-O-benzyl- $N$-(carboxypentyl)-1-C-ethyl-1,5dideoxy-1,5-imino-D-xylitol (25a, $\mathrm{C}_{34} \mathrm{H}_{43} \mathrm{NO}_{5}$ ) Compound 25 (60 $\mathrm{mg}, 0.11 \mathrm{mmol})$ was dissolved in $5 \mathrm{~cm}^{3}$ dioxane/ $\mathrm{H}_{2} \mathrm{O}(1 / 1, \mathrm{v} / \mathrm{v})$. $\mathrm{NaOH}$ solution ( $3 \mathrm{M}, 10$ drops) was added and the reaction mixture was stirred until the starting material was consumed (TLC cyclohexane/EtOAc $=2 / 1, \mathrm{v} / \mathrm{v})$. EtOAc was added and the reaction mixture was washed with $2 \mathrm{~N} \mathrm{HCl}$ and satd. $\mathrm{NaHCO}_{3}$ solution. The organic layer was dried over $\mathrm{Na}_{2} \mathrm{SO}_{4}$ and concentrated under reduced pressure. Compound 25a (40 mg) was obtained as colorless oil and was used without purification for the next step. $R_{f}=0.45$ $($ cyclohexane/EtOAc $=1 / 1, \mathrm{v} / \mathrm{v}) ;{ }^{1} \mathrm{H}$ NMR $(300 \mathrm{MHz}$, $\left.\mathrm{CDCl}_{3}\right): \delta=7.35-7.06(\mathrm{~m}, 15 \mathrm{H}, \mathrm{Ph}), 4.83-4.43(\mathrm{~m}, 6 \mathrm{H}$, $\mathrm{CH}_{2} \mathrm{Ph}$ ), 3.71-3.50 (m, 3H, H-2, H-3, H-4), 3.05-3.34 (m, 2H, H-1, H-5e), 2.68-2.42 (m, 3H, H-5a, H-8), 2.20 (t, 2H, H-12), 1.70-1.11 (m, 8H, H-6, H-9, H-10, H-11), 0.89 (t, $3 \mathrm{H}, \mathrm{H}-7) \mathrm{ppm} ;{ }^{13} \mathrm{C} \mathrm{NMR}\left(75.5 \mathrm{MHz}, \mathrm{CDCl}_{3}\right): \delta=178.2$ $(\mathrm{C}=\mathrm{O}), 139.1,138.7,138.6\left(3 \mathrm{x} \mathrm{C}_{\mathrm{q}}\right), 128.6-127.7(\mathrm{Ph}), 81.0$, 79.3, 77.3 (C-2, C-3, C-4), 75.2, 73.2, 73,0 (3x $\left.\mathrm{CH}_{2}-\mathrm{Ph}\right)$, 61.0 (C-1), 53.4 (C-8), 48.3 (C-5), 34.6 (C-12), 27.0, 26.6, 24.9 (C-9, C-10, C-11), 16.4 (C-6), 13.4 (C-7) ppm.

(1R)-2,3,4-Tri-O-benzyl-1-C-ethyl- $N$-[(imidazo-4-yl)ethylaminocarbonylpentyl]-1,5-dideoxy-1,5-imino-D-xylitol (27, $\left.\mathrm{C}_{39} \mathrm{H}_{50} \mathrm{~N}_{4} \mathrm{O}_{4}\right)$ Compound $25 \mathrm{a}$ (400 mg, $0.73 \mathrm{mmol}$ ) was dissolved in $20 \mathrm{~cm}^{3}$ DMF. COMU (704 mg, $1.46 \mathrm{mmol}, 2 \mathrm{eq}$ ) and $509 \mathrm{~mm}^{3}$ DIEA (2.92 mmol, 4 eq) were added and the reaction mixture was stirred for $30 \mathrm{~min}$. Histamine dihydrochloride (203 $\mathrm{mg}, 1.10 \mathrm{mmol}, 1.5 \mathrm{eq}$ ) was added to the reaction mixture and stirred until the starting material was consumed (TLC EtOAc/MeOH=10/1, v/v). The reaction mixture was concentrated under reduced pressure and purified by silica gel chromatography $\left(\mathrm{CHCl}_{3} / \mathrm{MeOH} /\right.$ concd. $\left.\mathrm{NH}_{4} \mathrm{OH}=12 / 1 / 0.01, \mathrm{v} / \mathrm{v} / \mathrm{v}\right)$ to give compound $27(140 \mathrm{mg})$ as yellow solid with small impurities. $R_{f}=0.45$ (cyclohexane/EtOAc $=1 / 1, \mathrm{v} / \mathrm{v}) ; \mathrm{MS}: \mathrm{m} / z$ calcd. for $\mathrm{C}_{39} \mathrm{H}_{50} \mathrm{~N}_{4} \mathrm{O}_{4} \mathrm{Na}$ 661.3730, found 661.3705; ${ }^{1} \mathrm{H}$ NMR (300 MHz, MeOH- $\left.d_{4}\right)$ : $\delta=7.67$ (s, 1H, H-18), 7.40-7.26 (m, 15H, Ph), 6.90 (s, 1H, $\mathrm{H}-17), 4.82-4.52\left(\mathrm{~m}, 6 \mathrm{H}, \mathrm{CH}_{2} \mathrm{Ph}\right), 3.82-3.65$ (m, 3H, H-2, H-3, H-4), 3.45 (t, 2H, H-14), 3.12-3.00 (m, 2H, H-1, H-5e), 2.92-2.73 (m, 4H, H-5a, H-12, H-15), 2.19 (t, 2H, H-8), 1.79-1.23 (m, 8H, H-6, H-9, H-10, H-11), 0.93 (t, 3H, H-7) ppm; ${ }^{13} \mathrm{C}$ NMR $\left(75.5 \mathrm{MHz}, \mathrm{MeOH}-d_{4}\right): \delta=176.1(\mathrm{C}-13)$, 139.9, 139.7, 139.6 (3x C $), 136.0$ (C-18), 135.6 (C-16), 129.5-128.9 (Ph), $118.2(\mathrm{C}-17), 78.5(\mathrm{C}-3), 77.1$ (2C, C-2, $\mathrm{C}-4), 75.5,73.7,73.6$ (3x $\left.\mathrm{CH}_{2}-\mathrm{Ph}\right), 63.0(\mathrm{C}-1), 54.6$ (C-12), 50.5 (C-5), 40.3 (C-14), 37.0 (C-8), 27.7, 27.5, 27.0, 26.7 (C-9, C-10, C-11, C-15), 18.1 (C-6), 13.2 (C-7) ppm.
(1R)-1-C-Ethyl- $N$-[(imidazo-4-yl)ethylaminocarbonylpentyl]1,5-dideoxy-1,5-imino-D-xylitol $\left(28, \mathrm{C}_{18} \mathrm{H}_{32} \mathrm{~N}_{4} \mathrm{O}_{4}\right)$ Compound 27 (140 mg, $0.22 \mathrm{mmol}$ ) was dissolved in $5 \mathrm{~cm}^{3} \mathrm{MeOH} / \mathrm{H}_{2} \mathrm{O}$ $(1 / 1, v / v), \operatorname{Pd}(\mathrm{OH})_{2} / \mathrm{C}$ was added and the reaction mixture was stirred under hydrogen atmosphere at ambient pressure. Upon consumption of the starting material (detected by TLC, eluent: $\mathrm{CHCl}_{3} / \mathrm{MeOH} /$ concd. $\mathrm{NH}_{4} \mathrm{OH}=2 / 1 / 0.25$, $\mathrm{v} / \mathrm{v} / \mathrm{v}$ ), the reaction mixture was filtered, concentrated under reduced pressure, and purified by silica gel chromatography $\left(\mathrm{CHCl}_{3} / \mathrm{MeOH} /\right.$ concd. $\mathrm{NH}_{4} \mathrm{OH}=3 / 1 / 0.25$, v/v/v), which gave compound $28(70 \mathrm{mg})$ in a yield of $86 \%$ as colorless oil. $R_{f}=0.60\left(\mathrm{CHCl}_{3} / \mathrm{MeOH} /\right.$ concd $\mathrm{NH}_{4} \mathrm{OH}=2 / 1 / 0.25$, v/v/v); MS: $m / z$ calcd. for $\mathrm{C}_{18} \mathrm{H}_{32} \mathrm{~N}_{4} \mathrm{O}_{4} \mathrm{Na} 391.2321$, found $391.2384 ;[a]_{D}^{20}=+5.8\left(c=1.04, \mathrm{H}_{2} \mathrm{O}\right) ;{ }^{1} \mathrm{H}$ NMR $(300 \mathrm{MHz}$, $\mathrm{D}_{2} \mathrm{O}$ ): $\delta=7.95$ (s, 1H, H-18), 6.96 (s, 1H, H-17), 3.87 (ddd, $\left.J_{4.5 \mathrm{e}}=3.1 \mathrm{~Hz}, J_{4,5 \mathrm{a}}=6.3 \mathrm{~Hz}, J_{4,3}=5.6 \mathrm{~Hz}, 1 \mathrm{H}, \mathrm{H}-4\right), 3.82$ (dd, $\left.J_{2,1}=3.5 \mathrm{~Hz}, J_{2,3}=5.8 \mathrm{~Hz}, 1 \mathrm{H}, \mathrm{H}-2\right), 3.75(\mathrm{dd}, 1 \mathrm{H}, \mathrm{H}-3)$, 3.38 (t, 2H, H-14), 3.27-3.16 (m, 2H, H-1, H-5e), 2.98 (dd, $\left.J_{5 \mathrm{a}, 5 \mathrm{e}}=12.5 \mathrm{~Hz}, J_{4,5 \mathrm{a}}=6.4 \mathrm{~Hz}, 1 \mathrm{H}, \mathrm{H}-5 \mathrm{a}\right), 2.93(\mathrm{t}, 2 \mathrm{H}, \mathrm{H}-12)$, 2.76 (t, 2H, H-15), 2.13 (t, 2H, H-8), 1.79-1.42 (m, 6H, H-6, $\mathrm{H}-9, \mathrm{H}-11), 1.29-1.10$ (m, 2H, H-10), 0.92 (t, 3H, H-7) ppm; ${ }^{13} \mathrm{C}$ NMR (75.5 MHz, $\left.\mathrm{D}_{2} \mathrm{O}\right): \delta=176.6(\mathrm{C}-13), 134.7(\mathrm{C}-18)$, 133.0 (C-16), 116.8 (C-17), 69.4 (C-3), 68.6 (C-4), 67.6 (C-2), 62.4 (C-1), 52.7 (C-12), 51.8 (C-5), 38.4 (C-14), 35.4 (C-8), 25.4 (C-10), 25.2 (C-9), 24.9 (C-15), 22.9 (C-11), 17.1 (C-6), 10.8 (C-7) ppm.

Acknowledgements Open access funding provided by Austrian Science Fund (FWF). Financial support by the FWF (Der Wissenschaftsfonds, Austria, P 30372-B21 as well as P 24815-B21) is gratefully acknowledged. P. W. thanks the Austrian Academy of Sciences for a DOC Grant (2017-2020). SGW thanks GlycoNet, the Canadian Network of Centres of Excellence in glycoscience, for financial support. MZ, MS, AW, PW, AES, and TMW gratefully acknowledge support from NAWI Graz.

Open Access This article is distributed under the terms of the Creative Commons Attribution 4.0 International License (http://creativeco mmons.org/licenses/by/4.0/), which permits unrestricted use, distribution, and reproduction in any medium, provided you give appropriate credit to the original author(s) and the source, provide a link to the Creative Commons license, and indicate if changes were made.

\section{References}

1. Noaki A, Cipolla L (eds) (2016) Iminosugars: the potential of carbohydrate analogs. From carbohydrate chemistry: state of the art and challenges for drug development. Imperial College Press, London

2. Compain P, Martin OR (eds) (2007) Iminosugars: from synthesis to therapeutic applications. Wiley, Chichester

3. Horne G, Wilson FX, Tinsley J, Williams DH, Storer R (2011) Drug Discov Today 16:107

4. Watson AA, Fleet GWJ, Asano N, Molyneux RJ, Nash RJ (2001) Phytochemistry 56:265 
5. Stütz AE (ed) (1999) Iminosugars as glycosidase inhibitors. Wiley, Weinheim

6. Nash RJ, Kato A, Yu C-Y, Fleet GWJ (2011) Future Med Chem $3: 1513$

7. Lv Z, Song C, Niu Y, Li Q, Ye X-S (2018) ChemMedChem $13: 338$

8. Bhuma N, Burade SS, Thierry L, Herman J, Kawade S, Doshi PJ, Dhavale DD (2018) Tetrahedron 74:852

9. Hsu C-H, Schelwies M, Enck S, Huang L-Y, Huang S-H, Chang Y-F, Cheng T-JR, Cheng W-C, Wong C-H (2014) J Org Chem 79:8629

10. Martin O, Gallienne-Boivineau E, Nicolas C, Heczko PB, Stochel G, Strus M, Kyziol A, Mikolajczyk DM, Machul A (2016) Preparation of imino alditols and their use as drugs for the treatment and/or the prevention of infection(s) caused by biofilm-forming bacteria. PCT Int. Appl. WO 2016030434 A1, Mar 3, 2016; (2016) Chem Abstr 164:350088

11. Alonzi DS, Scott KA, Dwek RA, Zitzmann N (2017) Biochem Soc Trans 45:571

12. Sayce AC, Alonzi DS, Killingbeck SS, Tyrrell BE, Hill ML, Caputo AT, Iwaki R, Kinami K, Die D, Kiappes JL, Beatty PR, Kato A, Harris E, Dwek RA, Miller JL, Zitzmann N (2016) PLOS 10:e0004254/1

13. Gueder N, Alla G, Marie-Sophie T, Hague F, Fernandez JM, Sanchez-Fernandez EM, Ortiz-Mellet C, Ahidouch A, OuadidAhidouch H (2017) Cell Physiol 232:3631

14. Evans GB, Tyler PC, Schramm VL (2018) ACS Infect Dis 4:107

15. Rugen MD, Vernet MMJL, Hantouti L, Soenes A, Andriotis VME, Rejzek M, Brett P, van den Berg RJBHN, Aerts JMFG, Overkleeft HS, Field RA (2018) Nat Sci Rep 8:16421

16. Sanchez-Fernandez EM, Garcia Fernandez JM, Ortiz-Mellet C (2016) ChemComm 52:5497

17. Mohamed FE, Al-Gazali L, Al-Jasmi F, Ali BR (2017) Front Pharmacol 8:448

18. Vitner EB, Platt FM, Futerman AH (2010) J Biol Chem 285:20423

19. Lahav D, Liu B, van den Berg RJBHN, van den Nieuwendijk AMCH, Wennekes T, Ghisaidoobe AT, Breen I, Farrez MJ, Kuo C-L, Liang W, Geurink PP, Ovaa H, van der Marel GA, van der Stelt M, Boot RG, Davies GJ, Aerts JMFG, Overkleeft HS (2017) J Am Chem Soc 139:14192

20. Schröder SP, van de Sande JW, Kallemejin WW, Kuo C-L, Artola M, van Rooden EJ, Jiang J, Beenakker TJM, Florea BI, Offen WA, Davies GJ, Minnaard AJ, Aerts JMFG, Codee JDC, van der Marel GA, Overkleeft HS (2017) Chem Commun 53:12528

21. Willems LI, Jiang J, Li K-Y, Witte MD, Kallemeijn WW, Beenakker TJN, Schröder SP, Aerts JMFG, van der Marel GA, Codee JDC, Overkleeft HS (2014) Chem Eur J 20:10864

22. Prichard K, Campkin D, O'Brian N, Kato A, Fleet GWJ, Simone MI (2018) Chem Biol Drug Des 92:1171
23. Bhuma N, Burade SS, Lout T, Herman J, Kawade S, Doshi PJ, Dhavale DD (2018) Tetrahedron 74:852

24. Lehmann J, Rob B (1995) Carbohydr Res 272:C11

25. Sevsek A, Srot L, Rither J, Celan M, van Uffors LQ, Moret EE, Martin NI, Pieters RJ (2017) ChemMedChem 12:483

26. Sevsek A, Torano JS, van Ufford LQ, Moret EE, Pieters RJ, Martin NI (2017) MedChemComm 8:2050

27. Katakam K, Umarani P, Fereshteh M (2017) World J Pharmaceut Res 8:563

28. Häusler H, Rupitz K, Stütz AE, Withers SG (2002) Monatsh Chem 133:555

29. Steiner AJ, Stütz AE, Tarling CA, Withers SG, Wrodnigg TM (2009) Aust J Chem 62:553

30. Compain P, Martin OR, Boucheron C, Godin G, Liang Yu, Ikeda K, Asano N (2006) ChemBioChem 7:1356

31. Oulaidi F, Gallienne E, Compain P, Martin OR (2011) Tetrahedron Asymm 22:609

32. Biela A, Oulaidi F, Gallienne E, Gorecki M, Frelek J, Martin OR (2013) Tetrahedron 69:3348

33. Oulaidi F, Front-Deschamps S, Gallienne E, Lesellier E, Ikeda K, Asano N, Compain P, Martin OR (2011) ChemMedChem 6:353

34. Schönemann W, Gallienne E, Ikeda-Obatake K, Asano N, Nakagawa S, Kato A, Adachi I, Gorecki M, Frelek J, Martin OR (2013) ChemMedChem 8:1805

35. Decrooq C, Laparra LM, Rodriguez-Lucena D, Compain P (2011) J Carbohydr Chem 30:559

36. Serra-Vinardell J, Diaz L, Casa J, Grinberg D, Vilageliu L, Michelakakis H, Mavridou I, Aerts JMFG, Decroocq C, Compain P, Delgado A (2014) ChemMedChem 9:1744

37. Goddard-Borger ED, Tropak MB, Yonekawa S, Tysoe C, Mahuran DJ, Withers SG (2012) J Med Chem 55:2737

38. Wennekes T, van den Berg RJBHN, Boltje TJ, Donker-Koopman WE, Kuijper B, van der Marel GA, Strijland A, Verhagen CP, Aerts JMFG, Overkleeft HS (2010) Eur J Org Chem:1258

39. Zoidl M, Müller B, Torvisco A, Tysoe C, Benazza M, Siriwardena A, Withers SG, Wrodnigg TM (2014) Bioorg Med Chem Lett 24:2777

40. Zoidl M, Gonzalez Santana A, Torvisco A, Tysoe C, Siriwardena A, Withers SG, Wrodnigg TM (2016) Carbohydr Res 429:62

41. Prade H, Mackenzie LF, Withers SG (1998) Carbohydr Res 305:371

42. Kempton JB, Withers SG (1992) Biochemistry 31:9961

43. Mayer C, Zechel DL, Reid SP, Warren RAJ, Withers SG (2000) FEBS Lett 466:40

Publisher's Note Springer Nature remains neutral with regard to jurisdictional claims in published maps and institutional affiliations. 